\title{
Genetic Heterogeneity among Isolates of Coxiella burnetii
}

\author{
By MICHAEL H. VODKIN,${ }^{1 *}$ JIM C. WILLIAMS ${ }^{1,2}$ AND \\ EDW ARD H. STEPHENSON ${ }^{1}$ \\ ${ }^{1}$ US Army Medical Research Institute of Infectious Diseases, Airborne Diseases Division, \\ Rickettsial Diseases Laboratory, Fort Detrick, Frederick, MD 21701-5011, USA \\ ${ }^{2}$ National Institute of Allergy and Infectious Diseases, Office of the Scientific Director, Bethesda, \\ MD 20204, USA
}

(Received 29 July 1985)

\begin{abstract}
Chromosomal and plasmid DNA have been extracted from six isolates of Coxiella burnetii, the aetiological agent of $\mathrm{Q}$ fever. Restriction fragment length polymorphisms detected after HaeIII digestions of chromosomal DNA revealed four different patterns that distinguished the American from the European isolates, and the Nine Mile phase I prototype strain from a spontaneously derived, isogenic phase II nonrevertant variant. At least one of the HaeIII fragments visible in the pattern from Nine Mile phase I and not in that from Nine Mile phase II could not be detected by DNA-DNA hybridization, and thus may have been deleted during the phase transition. Comparison of Nine Mile phase II, which does not survive animal passage, with Grita M44 phase II, which does, indicated that the HaeIII fragment was present in the Grita strain. These results suggest that this HaellI fragment may be concerned with functions necessary to survive the cellular immune response in vivo. Isolates from two human endocarditis cases showed the greatest divergence from all the other isolates, having at least five fragments of unique mobility in the HaeIII digestion pattern of their chromosomal DNA. Also, a plasmid obtained from these two isolates was 2 to $3 \mathrm{~kb}$ larger than the plasmid present in the other five isolates, and its restriction pattern could be distinguished from that of the other plasmids by several endonucleases. Detection of chromosomal and plasmid restriction fragment length polymorphisms among strains of phase I or phase II C. burnetii from various geographical locations and environmental sources will facilitate $Q$ fever diagnosis and strain identification.
\end{abstract}

\section{INTRODUCTION}

Coxiella burnetii, the aetiological agent of $\mathrm{Q}$ fever, has been identified in various environments (Benson et al., 1963; De Lay et al., 1950; Marmion \& Stoker, 1950), arthropod vectors (Babudieri, 1953; Cox, 1939; Davis \& Cox, 1938) and animals (Biberstein et al., 1974; Derrick \& Smith, 1940; Marshak et al., 1961). The diverse geographical distribution of C. burnetii has resulted in the accumulation of various isolates which appear to be serologically similar (Benson et al., 1963; Biberstein et al., 1974; Kazar et al., 1974; see also Table 1). Historically, isolation of $C$. burnetii by inoculation of animals with suspect samples (Derrick, 1937) yielded highly infectious and environmentally stable micro-organisms (Burnet \& Freeman, 1937). Interest in the development of vaccines for $\mathrm{Q}$ fever led to the discovery of phase variation (Stoker \& Fiset, 1956), which appears to be a host-controlled phenomenon. Virulent phase I $C$. burnetii may be isolated from the spleen and other tissues of infected, immunocompetent animals, whereas avirulent phase II micro-organisms are isolated after serial passage in the yolk sacs of embryonated eggs (Kazar et al., 1974) or in tissue culture (Burton et al., 1978). The principal biological and immunological differences between micro-organisms in the two phases are easily measured since phase I is characterized by a smooth lipopolysaccharide (LPS) and phase II by a rough LPS (Amano \& Williams, 1984; Schramek \& Mayer, 1982). Although 
various antigenic and immunogenic differences exist between phase I and phase II (Williams et al., 1981, 1984; Williams \& Stewart, 1984), no distinct serological or obvious biological differences have been demonstrated among geographically disparate phase $I$ isolates.

Infection of humans with $C$. burnetii produces disease which has been characterized by acute, flu-like, primary $Q$ fever, as a subacute granulomatous hepatitis, or as a chronic endocarditis with or without hepatitis (Peacock et al., 1983). Reports of persistent infection apparently acquired from contaminated animals have generated concern about the genetic or environmental factors involved in producing $C$. burnetii variants of sufficient virulence to establish chronic $Q$ fever in humans and animals. The study of the molecular pathogenesis of $C$. burnetii or the regulation and function of specific components of phase I and phase II microorganisms has been limited by the difficulty in genetically analysing this obligate intraphagolysosomal pathogen (Hackstadt \& Williams, 1981). Samuel et al. (1983) isolated a $36 \mathrm{~kb}$ plasmid from both phase I and phase II cells of the Nine Mile strain and designated them QpHI and QpHII, respectively. Restriction endonuclease cleavage maps of QpHI and QpHII suggested that the plasmids were very similar (Samuel et al., 1983), but the data did not exclude a role of the plasmids in virulence expression. In addition, HaeIII endonuclease digestions of chromosomal DNA showed minor differences between the genomes of the two phase variants (O'Rourke et al., 1984).

Since any vaccine that is developed must induce protection against an array of strains, we began a study of genomic and plasmid DNA to characterize the possible genetic heterogeneity among geographically and biologically selected isolates of $C$. burnetii. Isolates of $C$. burnetii from various geographical locations and of apparently varying degrees of virulence are available (Table 1). This piqued our interest in comparing restriction endonuclease cleavage maps of DNA of different isolates of $C$. burnetii to the Nine Mile prototype strain in phase I and phase II. By using specific probes generated from selected restriction fragments, we show genetic heterogeneity among isolates of $C$. burnetii.

\section{METHODS}

Rickettsial strains. Isolates of Coxiella burnetii, their source and their passage history are given in Table 1. The prototypes were clone 7 of phase I Nine Mile strain (CB9MIC7) and clone 4 of phase II Nine Mile strain (CB9MIIC4) (Cox \& Bell, 1939; Davis \& Cox, 1938; Williams et al., 1981). Three additional isolates were in phase I: Ohio strain (CBOI) (Reed \& Wentworth, 1957), PAV strain (CBPAVI), KAV strain (CBKAVI) (Kimbrough et al., 1979), and Henzerling strain (CBHENI) (Robbins et al., 1946). The M44 strain (CBM44II) (Genig, 1960; Johnson et al., 1976) was in phase II.

Culture conditions. C. burnetii was grown in yolk sacs of embryonated chicken eggs, purified via Renografin gradient procedures (Williams et al., 1981), and tested for other bacterial contamination on blood agar plates and thioglycolate medium. Media were inoculated with $0 \cdot 1 \mathrm{ml}$ of freshly purified C. burnetii, then incubated at $36^{\circ} \mathrm{C}$ in a humidified incubator for $15 \mathrm{~d}$. Dry weight of harvested micro-organisms was estimated from measurements of $\mathrm{OD}_{420}$ (Williams et al., 1981).

DNA extraction and purification. C. burnetii was resuspended at a final concentration of $1 \mathrm{mg} \mathrm{ml}^{-1}$ in lysozyme $\left(1 \mathrm{mg} \mathrm{ml}^{-1}\right)$ in $100 \mathrm{~mm}$-Tris/ $\mathrm{HCl}(\mathrm{pH} \mathrm{7.4)}$ containing $1 \mathrm{mM}$-EDTA and $15 \%(\mathrm{w} / \mathrm{v})$ sucrose. The suspension was incubated at $37^{\circ} \mathrm{C}$ for $30 \mathrm{~min}$. One-half the volume of $100 \mathrm{~mm}$-Tris ( $\left.\mathrm{pH} 12.0\right), 1 \mathrm{~mm}$-EDTA and $5 \%(\mathrm{w} / \mathrm{v})$ SDS was added and incubation was continued for $30 \mathrm{~min}$ at $56^{\circ} \mathrm{C}$. Protein was removed from the lysate with an equal volume of chloroform/buffer-saturated phenol $(1: 1, \mathrm{v} / \mathrm{v})$. DNA was precipitated from solution with 2 vols cold $\left(-20{ }^{\circ} \mathrm{C}\right) 95 \%(\mathrm{v} / \mathrm{v})$ ethanol. Chromosomal and plasmid (circular) DNAs were separated by centrifugation through an ethidium bromide/ $\mathrm{CsCl}$ gradient (Maniatis et al., 1982).

Restriction enzymes were used according to the instructions provided by the supplier (BRL). DNA fragments were analysed on $0.8 \%$ agarose gels in $89 \mathrm{mM}$-Tris ( $\mathrm{pH} 8.3$ ) containing $89 \mathrm{~mm}$-boric acid and $2.5 \mathrm{~mm}$-EDTA. For purification of DNA restriction fragments, agarose gels were stained in ethidium bromide $\left(1 \mu \mathrm{g} \mathrm{ml}^{-1}\right)$ in running buffer and visualized under long-wavelength UV light. The desired DNA fragment was excised, placed in dialysis tubing, and electroeluted at $100 \mathrm{~V}$ for $2 \mathrm{~h}$. Current was transiently reversed to remove DNA from the inner wall of the tubing. Agarose particles were removed by filtering through a BioRad Econo column followed by extracting with buffer-equilibrated phenol. DNA was concentrated by ethanol precipitation.

DNA was radiolabelled in vitro by the protocol of Rigby et al. (1977). DNA blotting was done by the procedure of Southern (1975). Hybridizations occurred at $68{ }^{\circ} \mathrm{C}$ in $2.5 \mathrm{ml} 2 \times \mathrm{SSC}(1 \times \mathrm{SSC}$ is $0.15 \mathrm{M}-\mathrm{NaCl}, 0.015 \mathrm{M}$-sodium citrate, $\mathrm{pH} 7.0$ ). Filters were washed at the same temperature in three $20 \mathrm{~min}$ rinses of $0.25 \% \mathrm{SDS} / 4 \times \mathrm{SSC}$. 
Table 1. Coxiella burnetii isolates

\begin{tabular}{|c|c|c|c|c|}
\hline Strain* & $\begin{array}{l}\text { Geographical } \\
\text { location }\end{array}$ & Source & Passage history $†$ & Phase $\ddagger$ \\
\hline $\begin{array}{l}\text { Nine Mile } \\
\text { (CB9MIC7) } \\
\text { (CB9MIIC4) }\end{array}$ & Montana§ & Tick & $\begin{array}{l}1 \mathrm{TP} / 307 \mathrm{GP} / 1 \mathrm{TC} / 2 \mathrm{EP} / 1 \mathrm{MP} / 2 \mathrm{EP} \\
1 \mathrm{TP} / 304 \mathrm{GP} / 90 \mathrm{EP} / 1 \mathrm{TC} / 4 \mathrm{EP}\end{array}$ & $\begin{array}{r}\text { I } \\
\text { II }\end{array}$ \\
\hline Ohio (CBOI) & Ohio & Bovine milk & $1 \mathrm{BP} / 5 \mathrm{EP} / 2 \mathrm{GP} / 2 \mathrm{EP}$ & I \\
\hline PAV (CBPAVI) & California & Human aortic valve & $1 \mathrm{HP} / 5 \mathrm{EP}$ & I \\
\hline $\begin{array}{l}\text { KAV (CBKAVI) } \\
\text { Henzerling }\end{array}$ & Oregon & Human aortic valve & $1 \mathrm{HP} / 1 \mathrm{GP} / 3 \mathrm{EP}$ & I \\
\hline $\begin{array}{l}\text { (CBHENI) } \\
\text { M44 (CBM44II) }\end{array}$ & $\begin{array}{l}\text { Italy } \\
\text { Greece }\end{array}$ & $\begin{array}{l}\text { Human blood clot } \\
\text { Human blood }\end{array}$ & $\begin{array}{l}1 \mathrm{HP} / 6 \mathrm{GP} / 25 \mathrm{EP} / 1 \mathrm{GP} / 2 \mathrm{EP} \\
1 \mathrm{HP} / 1 \mathrm{GP} / 86 \mathrm{EP} / 20 \mathrm{GP} / 50 \mathrm{MP} / 5 \mathrm{EP}\end{array}$ & $\begin{array}{l}\text { I } \\
\text { II }\end{array}$ \\
\hline
\end{tabular}

\section{RESULTS}

Analysis of chromosomal DNA. Chromosomal DNA prepared from each of the independent $C$. burnetii isolates (Table 1) was digested with HaeIII, and the DNA fragments were analysed on agarose gels. Since the HaeIII restriction patterns of CB9MIC7 and CB9MIIC4 were different, several other isolates were analysed with the same endonuclease (Fig. 1). Several differences and similarities among the DNAs were apparent. The 10 largest DNA fragments (bands) of the prototype $\mathrm{CB} 9 \mathrm{MIC} 7$ were assigned numbers according to the molecular sizes of the fragments, which varied between 2.5 and $4.5 \mathrm{~kb}$. Visualized differences are summarized as follows: (i) at least two bands, 1 and 3, present in CB9MIC7 (lane G), were not observed in CB9MIIC4 (lane E); (ii) band 1 was absent in both CB9MIIC4 and CBPAVI (lane F); (iii) the DNA pattern of the phase I American isolates, CB9MIC7 (lane G) and CBOI (lane B) were similar, whereas DNA patterns of the European isolates CBHENI (lane D) in phase I and CBM44II (lane C) in phase II appeared to be identical but they were distinguishable from the American isolates; (iv) the CBPAVI (lane F) and CBKAVI (not shown) isolates, from two endocarditis patients, were identical but they differed from all other isolates. In fact, CBPAVI appeared to have five unique DNA fragments within the 2.5 to $4.5 \mathrm{~kb}$ portion of the gel.

Probing with purified DNA fragments. The largest DNA fragment of CB9MIC7 (band 1) and of CBPAVI were sufficiently resolved to allow their purification by gel electrophoresis and electroelution. These two bands were purified, nick-translated with ${ }^{32} \mathrm{P}$-labelled precursor, and used as probe for the detection of homologous DNA from various isolates. Restriction fragment length polymorphism was detected after HaeIII digestions of chromosomal DNA of the different isolates by probing in homologous and heterologous DNA-DNA hybridizations. The largest DNA fragment of CB9MIC7 (band 1) did not correspond to any band in CB9MIIC4 nor did it hybridize to any material at that electrophoretic mobility (Fig. 2; compare lanes B and C). There was no evidence of hybridization of the probe with any DNA fragment of the gel in the CB9MIIC4 digest (Fig. 2, lanes C and D).

No analogue of band 1 of CB9MIC7 was detectable in the HaeIII digestion pattern of DNA from CBPAVI (lane D) or CBKAVI (not shown). However, the probe hybridized to two distinct fragments of CBPAVI and CBKAVI (not shown) with apparent sizes estimated to be 2.3 and $2.1 \mathrm{~kb}$. These two bands accounted for the $4.5 \mathrm{~kb}$ mass of the probe.

When the largest DNA fragment of CBPAVI also was used as a probe, it hybridized to itself and a corresponding band of the CBKAVI isolate (Fig. 3; compare lanes D and E). In the hybridizations of CB9MIC7 and CB9MIIC4 (lanes B and C), the signal localized to a region of the gel that was about $1 \mathrm{~kb}$ smaller than the probe. The new DNA fragment, predicted by the hybridization, corresponds to the fifth band of CB9MIC7. This fifth band was present in all of the isolates except CBPAVI (Fig. 1) and CBKAVI (not shown). 


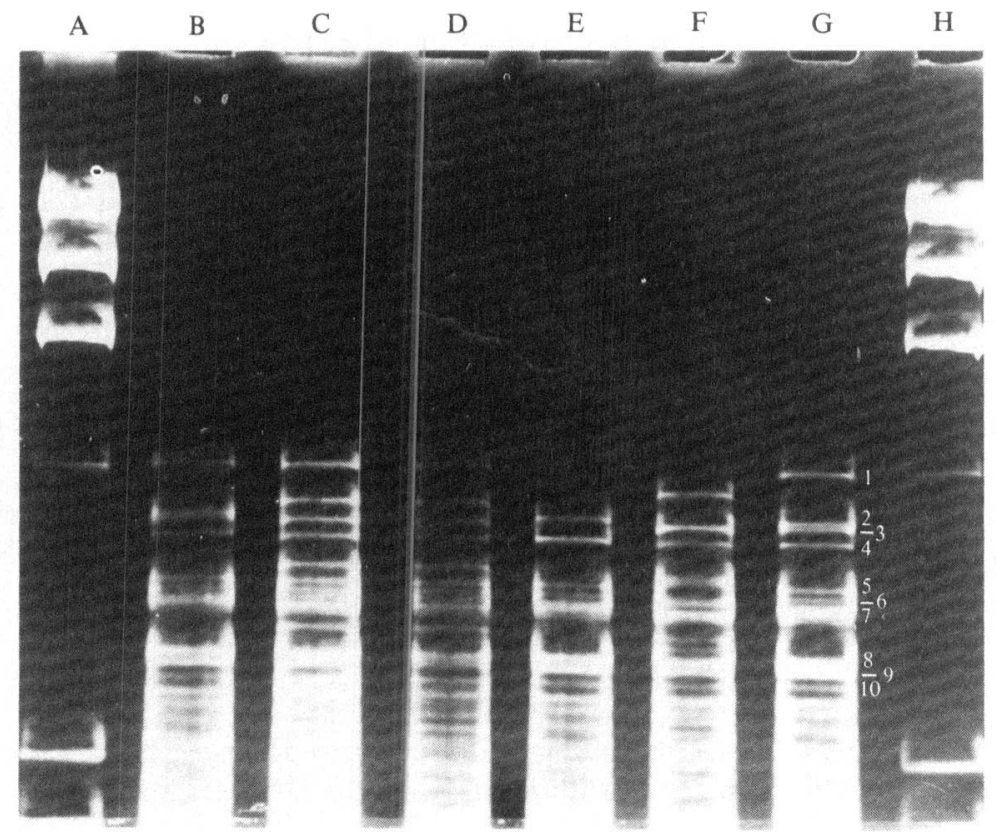

Fig. 1. Gel electropherogram of HaeIII digestion of chromosomal DNA from various isolates of $C$. burnetii. The chromosomal DNA of each isolate was digested with HaeIII and resolved on a $0.8 \%$ agarose gel. Lanes: $\mathrm{A}$ and $\mathrm{H}$, molecular weight markers, $\lambda$-Hind III; B, CBOI; C, CBM44II; D, CBHENI; E, CB9MIIC4; F, CBPAVI; G, CB9MIC7.

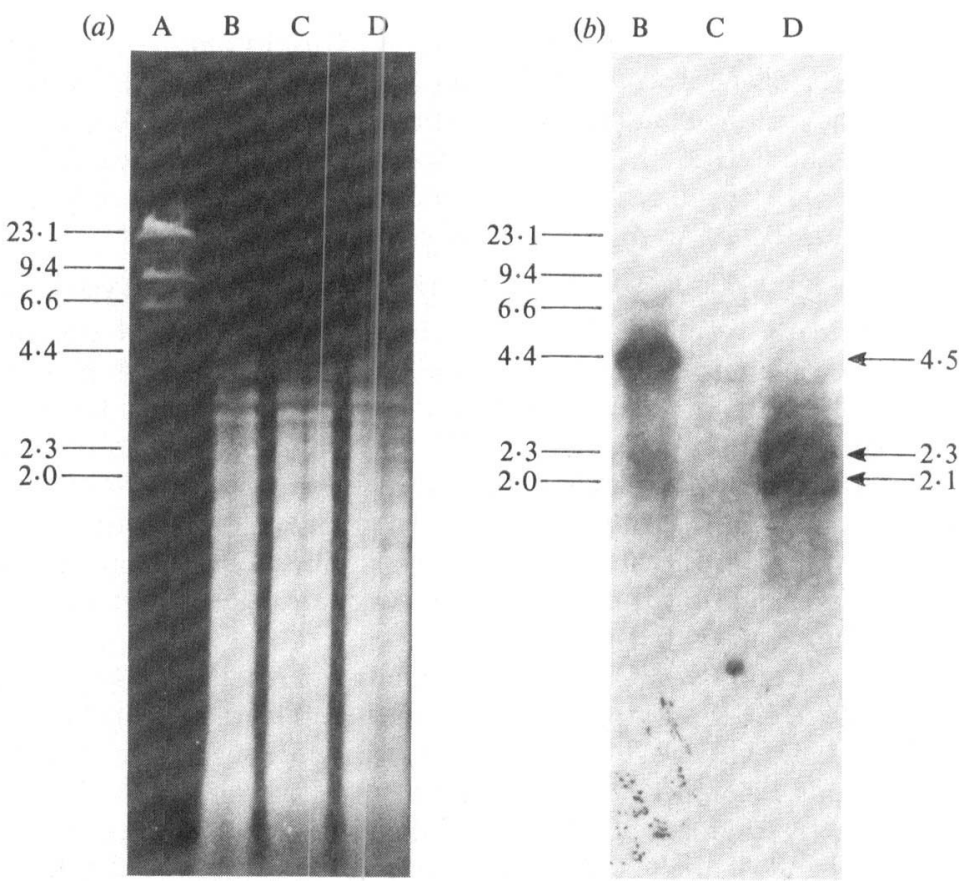

Fig. 2. Hybridization analysis of chromosomal DNA. HaellI-digested chromosomal DNA was hybridized with ${ }^{32}$ P-labelled DNA from band 1 of CB9MIC7 (Fig. 1, lane G) and $\lambda$ DNA. Lanes: A, $\lambda$ HindIII; B, CB9MIC7; C, CM9MIIC4; D, CBPAVI. (a) DNA visualized by ethidium bromide staining. (b) Pattern of hybridization as revealed by autoradiography. 


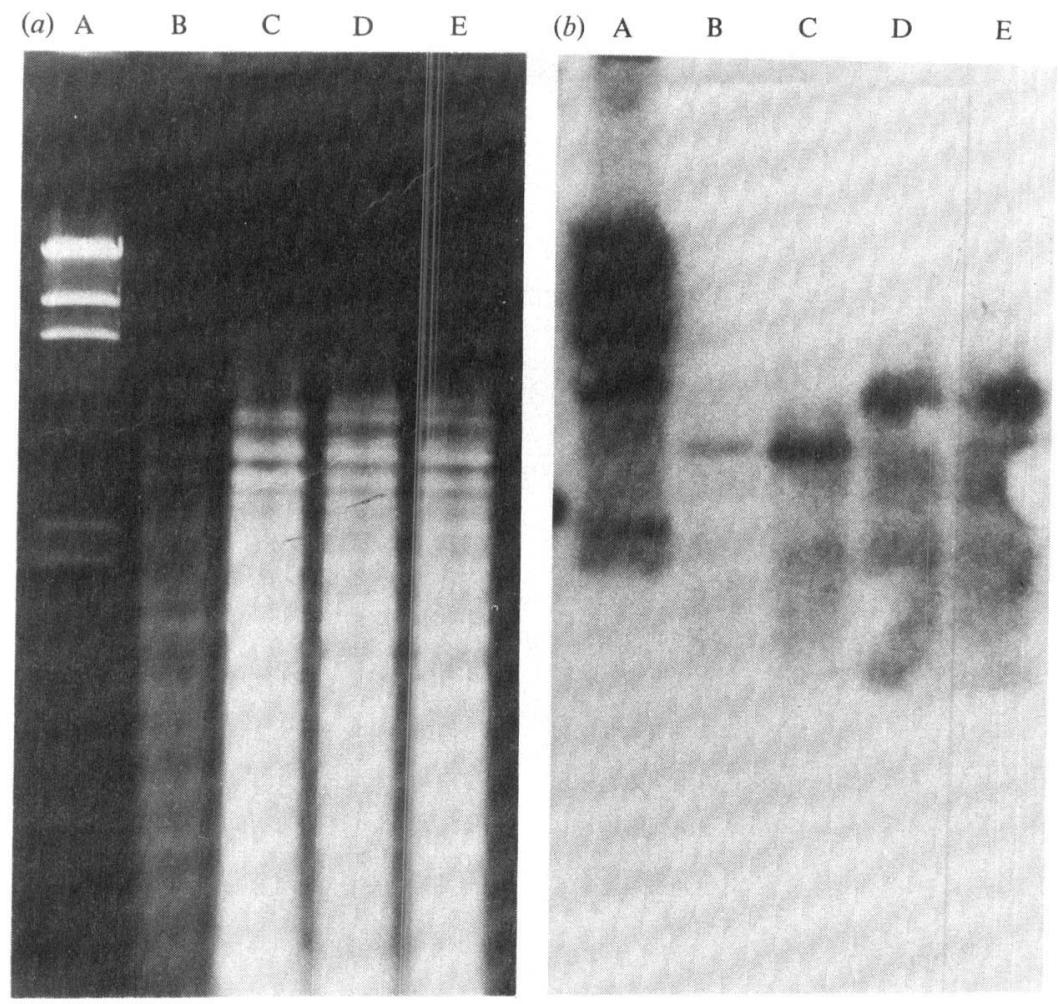

Fig. 3. Probing of chromosomal DNA of various isolates with the largest fragment of the HaeIII digestion of CBPAVI. Chromosomal DNAs and the probes were prepared as in Fig. 2. Lanes: A, $\lambda$ Hind III; B, CB9MIC7; C, CB9MIIC4; D, CBPAVI; E, CBKAVI. (a) DNA visualized by ethidium bromide staining. (b) Pattern of hybridization as revealed by autoradiography.

Restriction analysis of plasmid DNA. All the isolates of $C$. burnetii examined in this study contained a plasmid ranging in size from 36 to $40 \mathrm{~kb}$. The $36 \mathrm{~kb}$ size compared closely with the Nine Mile phase I and II plasmids (now designated pCB9MIC7 and pCB9MIIC4, respectively) described previously (Samuel et al., 1983). Our study shows that the plasmid isolated from the strains obtained from human heart valve tissue was 2 to $3 \mathrm{~kb}$ larger, and it exhibited a distinctly different restriction pattern (Figs 4 and 5). The restriction patterns of pCBOI and pCBM44II could not be distinguished from that of pCB9MIC7. Although the plasmids of the endocarditis strains (pCBPAVI and pCBKAVI) were indistinguishable, they also were markedly different from the other plasmids.

\section{DISCUSSION}

Taxonomic subdivisions within phase I $C$. burnetii historically have been based on geographical origin of the isolates. Phase variation which effectively attenuates the microorganism gives rise to phenotypic and serological differences between the isogenic pair. Differences among the phase I isolates were not easily demonstrated. In the current study we compared the restriction fragment length polymorphism of CB9MIC7 and CB9MIIC4 prototype strains and contrasted the American and European phase I and phase II isolates. The specificity of the restriction endonuclease patterns of chromosomal and plasmid DNA clearly delineated the American human endocarditis isolates from the tick and bovine isolates, while also distinguishing the European isolates from all others. Thus, we can reliably discriminate between these geographically disparate isolates, and we have attempted to define some of them 


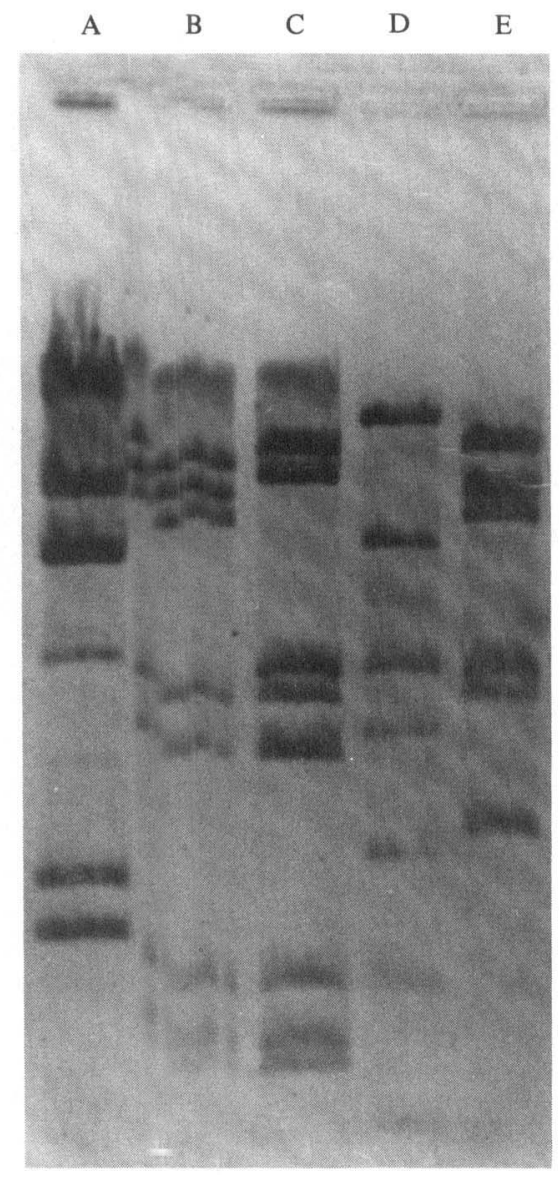

Fig. 4. BamHI and EcoRI digestions of pCB9MIC7 and pCBPAVI. Plasmid DNAs were purified as in Fig. 1. After digestion, fragments were analysed on a $0.8 \%$ agarose gel. Lanes: A, $\lambda$-Hind III; B, pCB9MIC7-BamHI; C, pCBPAVI-BamHI; D, pCB9MIC7-EcoRI; D, pCBPAVI-EcoRI.

as distinct strains. The human endocarditis isolates, also of American origin, can be resolved from either of the other groups. These molecular correlates may be used to designate strains, thereby facilitating both diagnosis and strain identification.

The prototype Nine Mile phase variant pair is one in which the phase II member does not survive upon repeated attempts to isolate viable phase I or phase II from the spleens of injected animals. Differences in HaeIII chromosomal DNA banding profiles between these two nearly isogenic strains may reflect genetic alterations during phase transition. Two of the three largest HaeIII fragments of the Nine Mile phase I chromosomal DNA are absent in Nine Mile phase II DNA (chromosomal and plasmid). Hybridization of sequences of the largest HaeIII band of phase I could not be detected in phase II. Thus, a deletion in the chromosomal DNf may have occurred. However, the possibility that the missing fragments involve a plasmid that is linear or subject to linearization cannot be excluded by these experiments. It is unknown whether the other missing bands in Nine Mile phase II also have been deleted and whether they are linked to the previous deletion. Inability of phase II to revert to phase I has not been correlated with a mutational event. Previous studies on the structure of $C$. burnetii LPS suggest that variation of molecular weight species are indicative of the smooth-to-rough mutational variation of saccharide chain length observed for Gram-negative Enterobacteriaceae (Goldman \& Leive, 1980; Schramek \& Mayer, 1982; Amano \& Williams, 1984). Although we have demonstrated sequence variations in chromosomal DNA segments between the CB9MIC7 and CB9MIIC4 
(a)

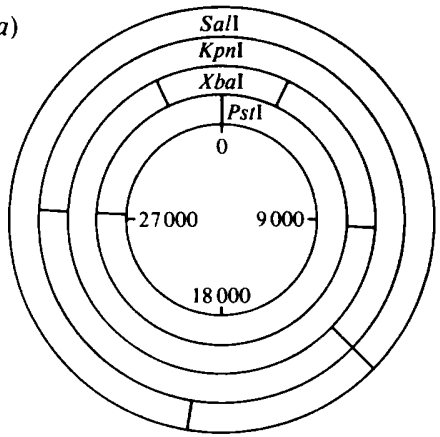

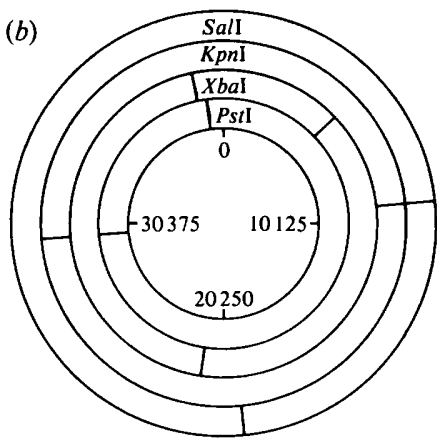

Fig. 5. Restriction maps of pCB9MIC7 (a) and pCBPAVI (b). Fragments were ordered by double digestions.

pair, the relationship of these genetic changes to LPS structural variation has not been strictly delineated.

The CBM44II strain was studied because this phase II strain survives in immunocompetent animals (Johnson et al., 1976), and it expresses the rough LPS chemotype (unpublished results) previously described for the CB9MIIC4 strain, which does not survive animal passage (Amano \& Williams, 1984). Comparison of the HaeIII chromosomal digests on electropherograms indicated that the CBM44II strain, in contrast to CB9MIIC4, still retained band 1. This genotypic difference between these two phase II isolates does not reflect any obvious serological differences. Therefore, the absence of band 1 is more closely related to the inability of CB9MIIC4 to survive in immunocompetent animals. The present evidence cannot distinguish whether this same DNA fragment also controls the transition of LPS from phase II to phase I chemotype, but it does not rule out the possibility that additional mutations affecting survivability and LPS biosynthesis have occurred concomitantly during phase transition.

All six isolates examined had a 36 to $40 \mathrm{~kb}$ plasmid. Plasmids from four of the six isolates gave identical cleavage patterns by both BamHI and EcoRI. The plasmids pCBPAVI and pCBKAVI appeared to be identical but they were markedly different from the other plasmids. The restriction patterns of pCBPAVI and pCBKAVI exhibited a 2 to $3 \mathrm{~kb}$ increase in size when examined with each of the two endonucleases, as well as with other enzymes. There is no apparent one-step process (inversion, translocation, etc.) that can explain the derivation of pCBPAVI from the plasmid prototype (pCB9MIC7) strain. The restriction maps of pCB9MIC7 and PCBPAVI indicated that multiple events have occurred in the evolution of this plasmid from the prototype plasmid. The disappearance of several EcoRI sites and the larger size of pCBPAVI also support the hypothesis that the endocarditis strains are markedly different from the common laboratory strains. Heteroduplex analysis of the plasmid DNA might clarify some of the events that generated the distinct profile of pCBPAVI.

C. burnetii is generally maintained in nature by cycles involving many species of animals, both herbivores and carnivores, as well as arthropods which become infected by taking a blood meal. Among domestic animals, female cattle, sheep, goats, dogs, cats and rabbits are involved in the cycle of infection. Man becomes incidentally infected via aerosols that originate primarily from contaminated animal products. These infectious cycles provide ecological niches which might select highly virulent genetic variants. In the present study we have described four variant chromosomal groups and two variant plasmid patterns of $C$. burnetii. The CBPAVI and CBKAVI strains have apparently undergone the greatest genetic change, presumably because of selective pressures generated by immunological responses combined with antibiotic therapy over a period of 10 or more years (Peacock et al., 1983). Alternatively, the origin of CBPAVI and CBKAVI may have been from another source (i.e. chronic disease of animals) via some unknown selection pressure or strain variation. Regardless of the source of these two isolates, this adaptation to a strain of higher virulence (i.e. establishment of chronic $Q$ fever) is a real 
concern which has influenced our approach to the classification of virulence mechanisms of $C$. burnetii. The phase I to phase II transition which effectively attenuates the virulent microorganisms also results in restriction fragment length polymorphism at the DNA level. It would be of interest to study the restriction patterns of several $C$. burnetii isolates from chronically infected animals and humans to test the idea that strains causing chronic disease may have singular conserved genotypes.

We are grateful to C. Bolt, J. Beveridge and R. Stockman for their technical assistance. We also wish to thank C. Snyder and $\mathbf{J}$. Lowe for their advice.

The views of the authors do not purport to reflect the positions of the Department of the Army or the Department of Defense.

\section{REFERENCES}

Amano, K.-I. \& Williams, J. C. (1984). Chemical and immunological characterization of lipopolysaccharides from phase I and phase II Coxiella burnetii. Journal of Bacteriology 160, 994-1002.

BABUDieri, B. (1953). Q fever: a zoonosis. Advances in Veterinary Science 5, 81-154.

Benson, W. W., Brook, D. W. \& Mather, J. (1963). Serologic analysis of a penitentiary group using raw milk from a $Q$ fever infected herd. Public Health Report 78, 707-710.

Biberstein, E. L., Behymer, D. E., Bushnell, R., Crenshaw, G., Riemann, H. P. \& Franti, C. E. (1974). A survey of $Q$ fever (Coxiella burnetii) in Californian dairy cows. American Journal of Veterinary Research 35, 1577-1582.

Burnet, F. M. \& Freeman, M. (1937). Experimental studies on virus of ' $Q$ ' fever. Medical Journal of Australia 2, 299--305.

Burton, P. R., Stueckemann, J., Welsh, R. M. \& PareTsky, D. (1978). Some ultrastructural effects of persistent infections by the rickettsia Coxiella burnetii in mouse $\mathrm{L}$ cells and green monkey kidney (Vero) cells. Infection and Immunity 21, 556-566.

Cox, H. R. (1939). Studies of filter-passing infectious agent isolated from ticks; further attempts to cultivate in cell-free media; suggested classification. Public Health Report 54, 1822-1827.

Cox, H. R. \& BELL, E. J. (1939). Cultivation of Rickettsia diaporica in tissue culture and in tissues of developing chick embryos. Public Health Report 54, 2171-2178.

Davis, G. E. \& Cox, H. R. (1938). Filter-passing infectious agent isolated from ticks; isolation from Dermacentor andersoni, reactions in animals, and filtration experiments. Public Health Report 53, 2259-2267.

De lay, P. D., Lennette, E. H. \& De Ome, K. B. (1950). Q fever in California; recovery of Coxiella burnetii from naturally-infected air-borne dust. Journal of Immunology 65, 211-220.

DERRICK, E. H. (1937). 'Q' fever, a new fever entity: clinical features, diagnosis and laboratory investigation. Medical Journal of Australia 2, 281-299.

DerRICK, E. H. \& SMITH, D. J. W. (1940). Studies in epidemiology of Q fever; the isolation of 3 strains of Rickettsia burnetii from the bandicoot Isoodon torosus. Australian Journal of Experimental Biology and Medical Science 18, 99-102.

GeniG, V. A. (1960). Attenuated variant ' $M$ ' of Rickettsia burnetii as a possible live vaccine against
Q-fever. Vestnik Akademii meditsinskikh nauk SSSR 2, 46-57 (in Russian).

Goldman, R. C. \& LEIVE, L. (1980). Heterogeneity of antigens - side chain length in lipopolysaccharide from Escherichia coli O111 and Salmonella typhimurium LT2. European Journal of Biochemistry 107, 145-153.

Hackstadt, T. \& Williams, J. C. (1981). Biochemical stratagem for obligate parasitism of eukaryotic cells by Coxiella burnetii. Proceedings of the National Academy of Sciences of the United States of America 78, 3240-3244.

Johnson, J. W., Eddy, G. A. \& Pedersen, C. E. JR (1976). Biological properties of the M-44 strain of Coxiella burneti. Journal of Infectious Diseases 133 , 334-338.

Kazar, J., Brezina, R., Schramek, S., Urvolgyi, J., Pospisil, V. \& Kovacova, E. (1974). Virulence, antigenic properties and physio-chemical characteristics of Coxiella burnetii strains with different chick embryo yolk sac passage history. Acta virologica 18 , 434-442.

Kimbrough, R. C., Ormsbee, R. A., Peacock, M., Rogers, W. R., Bennetts, R. W., RAaf, J., Krause, A. \& Gardner, C. (1979). Q fever endocarditis in the United States. Annals of Internal Medicine 91, 400-402.

Maniatis, T., Fritsch, E. F. \& Sambrook, J. (1982). Molecular Cloning: A Laboratory Manual. Cold Spring Harbor, NY: Cold Spring Harbor Laboratory.

Marmion, B. P. \& Stoker, M. G. P. (1950). Q fever in Great Britain; epidemiology of an outbreak. Lancet ii, 611--616.

Marshak, R. R., Melbin, J. \& Herman, M. J. (1961). Study of $Q$ fever in animals and man in Pennsylvania. American Journal of Public Health 51, 1189-1198.

O'Rourke, A. T., Samuel, J. E., Natvig, D. O., Frazier, M. E., Mallavia, L. P. \& Bacca, O. (1984). Restriction endonuclease analysis of phase I and phase II Coxiella burnetii DNA. In Abstracts of the Annual Meeting of the American Society for Microbiology, D67, p. 62. Edited by F. C. Neidhardt. Washington, DC: American Society for Microbiology.

Peacock, M. G., Philip, R. N., Williams, J. C. \& FAULKNER, R. S. (1983). Serological evaluation of $Q$ fever in humans: enhanced phase $I$ titers of immunoglobulins $\mathrm{G}$ and $\mathrm{A}$ are diagnostic for $\mathrm{Q}$ fever endocarditis. Infection and Immunity 41, 10891098. 
Reed, C. F. \& Wentworth, B. B. (1957). Q fever studies in Ohio. Journal of the American Veterinary Medical Association 130, 458-461.

Rigby, P. W. J., Dieckmann, M., Rhodes, C. \& Berg, P. (1977). Labeling deoxyribonucleic acid to high specific activity in vitro by nick translation with DNA polymerase 1. Journal of Molecular Biology 113, 237-251.

Robbins, F. C., Rustigian, R., Snyder, M. J. \& SMADEL, J. E. (1946). Q fever in the Mediterranean area: report of its occurrence in allied troops. III. The etiological agent. American Journal of Hygiene 44, 5163

Samuel, J. E., Frazier, M. E., Kahn, M. L., Thomashow, L. S. \& Mallavia, L. P. (1983). Isolation and characterization of a plasmid from phase I Coxiella burnetii. Infection and Immunity 41 , 488-493.

SCHRAMEK, S. \& MAYER, H. (1982). Different sugar compositions of lipopolysaccharides isolated from phase I and phase II cells of Coxiella burnetii. Infection and Immunity 38, 53-57.
Southern, E. M. (1975). Detection of specific sequences among DNA fragments separated by gel electrophoresis. Journal of Molecular Biology $\mathbf{9 8 ,}$ 503-517.

STOKER, M. G. P. \& FiseT, P. (1956). Phase variation of the Nine Mile and other strains of Rickettsia burnetii. Canadian Journal of Microbiology 2, 310--321.

Williams, J. C. \& STEWART, S. (1984). Identification of immunogenic proteins of Coxiella burnetii phase variants. In Microbiology - 1984, pp. 257-262. Edited by L. Leive \& D. Schlessinger. Washington, DC: American Society for Microbiology.

Williams, J. C., Peacock, M. G. \& MCCaul, T. F. (1981). Immunological and biological characterization of Coxiella burnetii, phases I and II, separated from host components. Infection and Immunity 32, $840-851$.

Williams, J. C., Johnston, M. R., Peacock, M. G., Thomas, L. A., Stewart, S. \& Portis, J. L. (1984). Monoclonal antibodies distinguish phase variants of Coxiella burnetii. Infection and Immunity 43, 421-428. 